\title{
Perforated Meckel's Diverticulum in a 3-day-old Neonate; A Case Report
}

\author{
Mehdi Frooghi ${ }^{1}$, Ali Bahador ${ }^{2}$, Alireza Golchini ${ }^{3}$, Mahmood Haghighat ${ }^{4}$, \\ Maryam Ataollahi ${ }^{*}$, Hazhir Javaherizadeh ${ }^{6}$
}

1. Fellow of Pediatric Surgery, Department of Pediatric Surgery, Nemazee Teaching Hospital, Shiraz University of Medical Sciences, Shiraz, Iran

2. Professor, Department of Pediatric Surgery, Nemazee Teaching Hospital, Shiraz University of Medical Sciences, Shiraz, Iran

3. Resident, Department of Pediatric Surgery, Nemazee Teaching Hospital, Shiraz University of Medical Sciences, Shiraz, Iran

4. Professor, Department of Pediatric Gastroenterology, Nemazee Teaching Hospital, Shiraz University of Medical Sciences, Shiraz, Iran

5. Fellow of Pediatric Gastroenterology, Department of Pediatric Gastroenterology, Nemazee Teaching Hospital, Shiraz University of Medical Sciences, Shiraz, Iran

6. Assistant Professor of Pediatric Gastroenterology, Abuzar Children's Hospital, Ahvaz Jundishapur University of Medical Sciences, Ahvaz, Iran

\section{* Corresponding Author:}

Maryam Ataollahi, MD

Fellow of Pediatric Gastroenterology, Department of Pediatric Gastroenterology, Nemazee Teaching Hospital, Shiraz University of Medical Sciences, Shiraz, Iran Postal code: 71939-11351

Tel: +98 7136125401

Fax: +98 7136125402

Email: Maryam.ataollahi@yahoo.com

Received: 06 Jun. 2016

Accepted: 06 Sep. 2016

\section{ABSTRACT}

Perforation of Meckel's diverticulum is a rare complication in neonatal period. A 3-dayold term male neonate was transferred to our emergency room due to bowel perforation. Surgical exploration was done and perforated Meckel's diverticulum was detected. Pathological report of the tissue showed inflamed diverticulum with heterotopic gastric mucosa. This is the first report of Meckel's diverticulum perforation in a neonate in our country

KEYWORDS: Bowel perforation, Meckel's diverticulum, Heterotopic gastric mucosa

Please cite this paper as:

Frooghi M, Bahador A, Golchini AR, Haghighat M, Ataollahi M, Javaherizadeh H. Perforated Meckel's Diverticulum in a 3-day-old neonate; A Case Report. Middle East J Dig Dis 2016;8:323-326. DOI :10.15171/mejdd.2016.43

\section{INTRODUCTION}

Meckel's' diverticulum (MD) is the most common congenital anomaly of the gastrointestinal tract. ${ }^{1}$ Symptomatic MD in the neonatal period is quite rare. Complication rate is about $4 \% .^{2}$ Intestinal perforation is a less common complication of MD in children that occurs in $10 \%$ of patients. ${ }^{3}$ It rarely occurs in neonatal period and only few cases have been reported until now in the literature. ${ }^{4}$

\section{CASE REPORT}

A 3-day-old male neonate was referred to our hospital because of repeated vomiting after breastfeeding. Vomiting was bilious and was associated with abdominal distention.

The neonate's birth weight was 3200 gr and he was born from a 28-year-old mother gravid 1 with uncomplicated pregnancy course and normal vaginal delivery with APGAR score 9 at min 1 , and 10 at min 5.

On admission, careful physical exam was done, which revealed tachycardia, hypotension, and severe abdominal distention, while the neonate was lethargic. Laboratory assessment was done in the first day of admission. White blood cell count was 8600 . Hemoglobin was $17.1 \mathrm{~g} / \mathrm{dL}$. Platelet count was 237000 (table 1). Blood urea nitrogen was $21 \mathrm{mg} / \mathrm{dL}$. Due to bilious vomiting, thoraco-abdominal radiography was done (figure1).

After physical examination and radiological evaluation the patient underwent exploratory laparotomy with the impression of bowel perforation. Free air was observed in abdomen. Bowel content was discovered 
Table 1: Laboratory investigation during hospital admission

\begin{tabular}{|c|c|c|c|c|c|c|c|}
\hline Lab data & 1st day & $2 d / 0$ & $3 d / 0$ & $4 d / 0$ & $5 d / 0$ & $6 d / 0$ & $7 d / 0$ \\
\hline White blood cell (cells/mcL) & 8600 & 10600 & 4700 & - & - & - & - \\
\hline Hemoglobin (gr/dL) & 17.1 & 16.7 & 10.3 & - & - & - & - \\
\hline $\mathrm{MCV}(\mathrm{fL})$ & - & 100.4 & 101 & - & - & - & - \\
\hline $\mathrm{MCH}(\mathrm{pg} / \mathrm{cell})$ & - & 34.9 & 23.3 & - & - & - & - \\
\hline $\mathrm{Cr}(\mathrm{mg} / \mathrm{dL})$ & 1.2 & 1 & 0.1 & - & - & - & 0.1 \\
\hline $\mathrm{Na}(\mathrm{meq} / \mathrm{L})$ & 139 & - & 142 & 138 & - & - & 144 \\
\hline $\mathrm{K}(\mathrm{meq} / \mathrm{L})$ & 4.6 & - & 4.6 & 6.8 & 4.7 & - & 5.4 \\
\hline $\mathrm{PCo}_{2}(\mathrm{mmHg})$ & - & 23 & 31.6 & - & - & - & - \\
\hline $\mathrm{Po}_{2}(\mathrm{mmHg})$ & - & 68 & 89 & - & - & - & - \\
\hline $\mathrm{Hco}_{3}(\mathrm{mEq} / \mathrm{L})$ & - & 16.9 & 21.4 & - & - & - & - \\
\hline
\end{tabular}

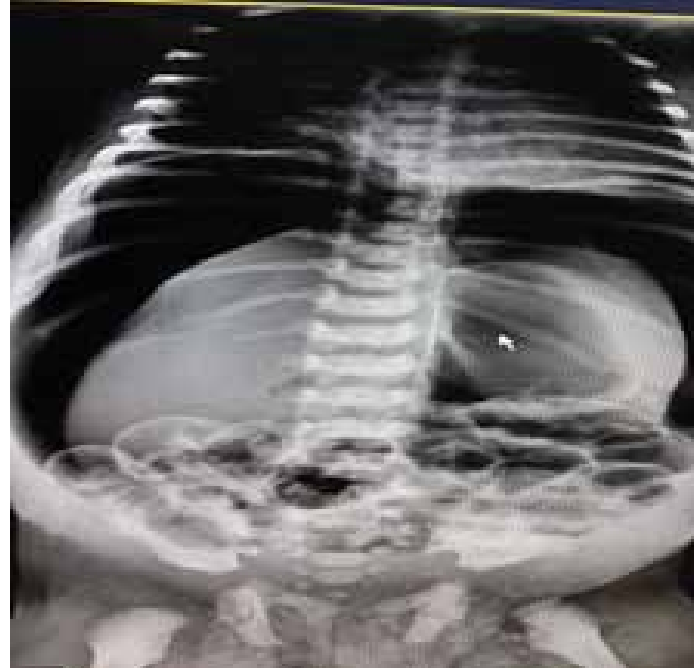

Fig.1: Significant amount of air was seen below the diaphragm. Both sides of bowel wall were well defined (Rigler's sign).

in abdomen too and perforated MD was diagnosed. Resection and irrigation with 1 liter normal saline was done.

Pathological report of tissue specimen was inflamed MD with heterotopic gastric mucosa. Five days after operation, nasogastric tube was discontinued and oral feeding with formula was started without any complication. Two days later ( 7 days of hospital admission) the neonate left the hospital with good condition.

\section{DISCUSSION:}

$\mathrm{MD}$ is a $3-6 \mathrm{~cm}$ outpouching from the antimesenteric border of the ileum at $50-75 \mathrm{~cm}$ from the ileocecal valve. Failure of involution of the omphalomesenteric duct during the 5 th and 7 th week of gestation, results in MD. MD contains four layers of intestine and may have different ectopic tissues such as gastric, pancreatic, colonic, duodenal, or endometrial in about $30 \%$ to $50 \%$ of patients. The omphalomesenteric artery that arises from an ileal branch of the superior mesenteric artery provides the blood supply of diverticulum.

Although MD is the most common congenital anomaly of the gastrointestinal tract, its symptomatic manifestation in the neonatal period is rare. Common presentations of neonatal Meckel's diverticulum that have been reported in the literature include perforation, intussusception, segmental ileal dilatation, and ileal volvulus. ${ }^{4-8}$ Perforation was one of our findings in the current report.

Most of the symptomatic MD occurs by the age of 3 years. It is more common in boys (male to female ratio $2: 1) .{ }^{9}$ In our report, a male neonate was affected.

Heterotopic gastric mucosa was reported in our patient. In other reports, heterotopic tissue was not found in some cases. ${ }^{10}$ 
Table 2: Reported cases of symptomatic neonatal Meckel's diverticulum in the literature

\begin{tabular}{|c|c|c|c|c|c|c|c|}
\hline Reference & Presentation & $\begin{array}{l}\text { Age } \\
\text { (day) }\end{array}$ & Sex & $\begin{array}{l}\text { Heterotop- } \\
\text { ic Tissue }\end{array}$ & Histology & $\begin{array}{c}\text { Associated } \\
\text { Abnormalities }\end{array}$ & Outcome \\
\hline Hunter $^{10}$ & Pneumoperitoneum & 4 & Male & None & Inflammation & None & Died \\
\hline Ford et al. ${ }^{11}$ & Pneumoperitoneum & 1 & $?$ & Pancreatic & $\begin{array}{c}\text { Inflammation \& } \\
\text { necrosis }\end{array}$ & VATER & Died \\
\hline Yeh et al. ${ }^{12}$ & Bowel obstruction & 8 & Male & None & $\begin{array}{c}\text { Inflammation \& } \\
\text { necrosis }\end{array}$ & None & $\begin{array}{l}\text { Discharged } \\
\text { to home }\end{array}$ \\
\hline Gandy et al. ${ }^{8}$ & Bowel obstruction & 4 & Male & Pancreatic & Acute inflammation & None & $\begin{array}{c}\text { Discharged } \\
\text { to home }\end{array}$ \\
\hline Zahraa et al. ${ }^{6}$ & Sepsis & 3 & Male & None & Inflammation & None & $\begin{array}{l}\text { Discharged } \\
\text { to home }\end{array}$ \\
\hline Chang et al. ${ }^{4}$ & Pneumoperitoneum & 1 & Male & None & Muscular defect & None & $\begin{array}{l}\text { Discharged } \\
\text { to home }\end{array}$ \\
\hline Oyachi et al. ${ }^{15}$ & Bowel obstruction & 14 & Male & None & Inflammation & None & $\begin{array}{l}\text { Discharged } \\
\text { to home }\end{array}$ \\
\hline
\end{tabular}

Pneumoperitoneum was reported in the literature .${ }^{10,11}$ Pneumoperitoneum was seen in our case.

Bowel obstruction is the most common presenting feature in neonates.$^{12}$ In our report, bowel obstruction with bilious vomiting was the first presentation. In the study by Bertozzi and colleagues bowel obstruction (58.3\%) and pneumoperitoneum $(33.3 \%)$ were the most common clinical manifestations of symptomatic MD among neonates.$^{13}$

Mild hypochloremic alkalosis was reported by Bertozzi and co-workers. ${ }^{13}$ In our case, mild alkalosis was found in the blood gas analysis. Incidence of perforated MD in neonates is very rare and this case is the first report from our country.

It should be considered that other causes of intestinal perforation in neonatal period include necrotizing enterocolitis (NEC), Hirschsprung's disease, meconium ileus in neonates with cystic fibrosis, intestinal atresia, and intestinal volvulus. ${ }^{3}$

MD perforation can be occurred due to either diverticulitis or heterotopic mucosa within the diverticulum. This has been proven in the last 25-year overview of MD perforation, which shows that about $75 \%$ of cases have acute inflammation and/ or heterotopic mucosa in their specimens. Other than the present patient only in three other patients, pancreatic heterotopic mucosa was identified, but it may occur spontaneously. In our report, inflamed MD with heterotopic gastric mucosa was found.

Other predisposing factors for MD perforation are: corticosteroid therapy in antenatal and postnatal period, maternal use of corticosteroids or cocaine, perinatal asphyxia or hypoxia, exchange transfusion, trauma due to feeding by nasogastric tube, congenital absence of muscle in gastrointestinal wall, and decreased intrauterine blood flow. ${ }^{14}$ None of these factors were detected in our patient.

There are only two mortality reports from perforated MD. The first one happened in 1927 when a 4-day-old neonate with abdominal distention and shock died and during autopsy evaluation perforated MD was diagnosed. ${ }^{10}$ The second case was a neonate with multiple congenital anomalies (esophageal atresia, tracheoesophageal fistula, and imperforate anus who died due to cardiorespiratory failure). ${ }^{11}$

Perforated MD in neonates can mimic several diseases such as NEC, perforated appendicitis, and solitary ileal perforation. Treatment is different, but confirming a preoperative diagnosis of MD in cases with signs of perforation is not necessary because prompt surgical intervention is mandatory if an intra-abdominal pathology is suspected. If diagnosis and management is done at proper time, good prognosis with about $100 \%$ survival will be expected for neonates with isolated perforated MD.

\section{CONFLICT OF INTEREST}

The authors declare no conflict of interest related to this work. 


\section{REFERENCES}

1. Mackey WC, Dineen P. A fifty year experience with Meckel's diverticulum. Surg Gynecol Obstet 1983,156:56-64.

2. Shalaby RY, Soliman SM, Fawy M, Samaha A. Laparoscopic management of Meckel's diverticulum in children. J Pediatr Surg 2005,40:562-7.

3. Aguayo P, Fraser JD, Peter SDS, Ostlie DJ. Perforated Meckel's diverticulum in a micropremature infant and review of the literature. Pediatr Surg Int 2009,25:539-41. doi:10.1007/s00383-009-2378-y

4. Chang YT, Lin JY, Huang YS. Spontaneous perforation of Meckel's diverticulum without peritonitis in a newborn: report of a case. Surg Today 2006,36:11147. doi:10.1007/s00595-006-3317-3

5. Sy ED, Shan YS, Yang YR, Tsai HM, Lin CH. Hirschsprung's disease, a rare precipitating factor in neonatal perforated Meckel's diverticulum. $J$ Pediatr Surg 2006,41:1319-21. doi: 10.1016/j.jpedsurg.2006.03.041

6. Zahraa J, Abu-Ekteish F, Al Bassam AR, Nosir AA. Perforated Meckel's diverticulum in a neonate mimicking necrotizing enterocolitis. Pediatr Emerg Care 2003,19:418-9.

7. Sy ED, Shan YS, Tsai HM, Lin CH. Meckel's diverticulum associated with ileal volvulus in a neonate. Pediatr Surg Int 2002,18:529-31. doi:10.1007/ s00383-002-0784-5

8. Gandy J, Byrne P, Lees G. Neonatal Meckel's diverticular inflammation with perforation. $J$ Pediatr Surg 1997,32:750-1. doi :10.1016/S0022-3468(97)90024-5

9. Yahchouchy EK, Marano AF, Etienne J-CF, Fingerhut AL. Meckel's diverticulum. J Am Coll Surg 2001,192:658-62.

10. Hunter WC. Perforated Gangrenous Meckel's Diverticulum in a New-Born Infant: Report of a Case. Am J Dis Child 1928,35:438-42. doi:10.1001/archpedi.1928.01920210083009

11. Ford EG, Woolley MM. Tracheoesophageal fistula associated with perforated Meckel's diverticulum. J Pediatr Surg 1992,27:1223-4. doi:10.1016/00223468(92)90793-7

12. Yeh JT, Lai HS, Duh YC. Perforated Meckel's diverticulum in a neonate. $J$ Formos Med Assoc 1996,95:644-5.

13. Bertozzi M, Melissa B, Radicioni M, Magrini E, Appignani A. Symptomatic Meckel's diverticulum in newborn: two interesting additional cases and review of literature. Pediatr Emerg Care 2013,29:1002-5. doi: 10.1097/PEC.0b013e3182a315e5

14. Kumar P, Ojha P, Singh UK. Spontaneous perforation of Meckel's diverticulum in a neonate. Indian Pediatr 1998,35:906-8.
15. Oyachi N, Takano K, Hasuda N, Arai H, Koshizuka K, Matsumoto M. Perforation of Meckel's diverticulum manifesting as aseptic peritonitis in a neonate: report of a case. Surg Today 2007,37:881-3. doi:10.1007/s00595-007-3519-3 